\title{
PERSEPSI MASYARAKAT DESA CIHANJUANG TENTANG DONOR DARAH: STUDI KUALITATIF
}

\author{
Evelin Malinti ${ }^{1}$, Yunus Elon ${ }^{1}$ \\ ${ }^{1}$ Fakultas Ilmu Keperawatan, Universitas Advent Indonesia \\ *email: yunus.elon@unai.edu
}

\begin{abstract}
Abstrak
Mendonorkan darah merupakan suatu tindakan mulia yang dapat menyelamatkan nyawa. Penelitian ini bertujuan untuk melihat persepsi masyarakat di Desa Cihanjunag tentang donor darah. Penelitian ini menggunakan metode qualitative, dimana informan sebagai sumber informasi utama. Ada 7 informan yang dipilih dengan menggunakan metode nonprobability sampling. Pengumpulan data dilakukan dengan cara mewawancarai dan merekam pernyataan informan, kemudian dibuat traskrip verbatim dan dianalisa untuk menentukan kognator. Hasil: Sebanyak $71 \%$ informan belum pernah donor darah, $29 \%$ sudah pernah mendonorkan darahnya. Hal yang diketahui informan tentang donor darah yaitu menyumbangkan darah, membentuk darah baru dan menolong orang lain. Informan bersedia mendonorkan darah kepada orang yang tidak dikenal dan jika ada yang membutuhkan. Perasaan Informan iklas, sukarela dan bantu orang lain, puas serta senang. Bagi informan, donor darah akan menyehatkan dan tidak merugikan serta mengatakan bahwa orang yang sedang haid tidak bisa mendonorkan darahnya. Kesimpulan : Walaupun mayoritas informan belum pernah mendonorkan darah, informan memiliki pandangan postif dan bersedia untuk mendonorkan darah bagi yang membutuhkan.
\end{abstract}

Kata Kunci : Donor darah, Persepsi, Emik, Kategorik

\begin{abstract}
Donating blood is a noble act that can save lives. The study aimed to assess the perception of the community in Cihanjuang Village about blood donation. The study utilized a qualitative method, where informants were the main source of information. A total of 7 informants who were selected using the nonprobability sampling method. The data was collected by interviewing and recording the statements of the informants, then verbatim transcripts were made and analyzed to determine the cognator. Results: As many as $71 \%$ of informants have never donated blood, 29\% have donated blood. What informants know about blood donation is donating blood, forming new blood and helping others. Informants are willing to donate blood to strangers and if someone is in need. Feelings Informants are sincere, volunteer and help others, are satisfied and happy. For the informants, blood donation would be healthy and not harmful and said that people who are menstruating cannot donate blood. Conclusion: Although the majority of informants have never donated blood, the informants have a positive view and are willing to donate blood for those in need
\end{abstract}

Key words : Blood donation, Perception, emic, Categorick, 


\section{PENDAHULUAN}

Darah merupakan cairan vital yang mengalir keseluruh jaringan tubuh melalui pembuluh darah, dengan membawa oxygen dan nutrisi yang merupakan makanan selsel tubuh mahkluk hidup. Beberapa kondisi dimana seseorang membutuhkan transfusi darah antara lain; Anemia, Penyakit sickle cell, hemophilia atau ganguan darah yang menyebabkan pendarahan, kanker, trauma internal dan external yang mengakibatkan kehilangan darah serta perdarahan (Bethesda, 2017). Kebutuhan akan darah terus mengalami peningkatan di dunia ini, 1 dari 7 pasien atau $14,2 \%$ pasien yang dirawat memerlukan transfusi darah. Dan terjadi disparitas yang tinggi antara kebutuhan darah dan jumlah darah yang didonorkan. Di US kebutuhan darah setiap harinya sekitar 36.000 unit, tapi jumlah tersebut masih kurang dari kebutuhan (American Red Cross, 2016).

Sementara di Indinesia, dalam 10 tahun terakhir (2007-2016) terjadi peningkatan donasi darah, baik donasi sukarela, donasi keluarga maupun donasi bayaran, namun jumlah donasi tersebut belum memenuhi kebutuhan darah di Indonesia. WHO memberikan ketentuan yakni kebutuhan darah minimal $2 \%$ dari jumlah penduduk, adapun jumlah penduduk pada tahun 2016 sebanyak 258.704.986 juta jiwa, maka idelanya dibutuhkan darah sebanyak 5.174.100 kantong darah, sementara yang tersedia 4.201.578 kantong darah atau minus 18.8\% (Pusdatin Kemenkes, 2018). Menurut kepala unit transfusi darah (UTD) kota bandung Uke Muktimanah, kebutuhan darah setiap hari sebanyak 500 labu sementara yang tersedia hanya 300 an labu (Firmansyah, 2020). Kondisi kekurangan stok darah saat ini, diperparah dengan pandemic covid-19, sebgaimana dikemukakan oleh ketua PMI Bapak Jusuf Kalla, yaitu banyak kegiatan yang tutup, masyarakat tidak keluar rumah sehingga terjadi kekurangan pasokan darah (Ernes, 2020).
Penelitian yang dilakukan di Iran terhadap 749 mahasiswa. $476(63.55 \%)$ wanita dan 273 (36.44\%) adalah pria. Rentang usia subjek 18-33 tahun. Dari 749 hanya 73 atau 9.74\% yang pernah mendonorkan darahnya sisanya $671(89.58 \%)$ tidak pernah mendonorkan darahnya. Dan dari 73 subjek yang mendonorkan darahnya, persentasi donor pria lebih tinggi di banding wanita. Penenlitian tersebut menyimpulkan kesadaran rendah dan sikap negative terhadap kegiatan donor darah (Majdabadi et al., 2018). Sebuah survey yang dilakukan di Guangzhou, China untuk melihat faktorfaktor yang mempengaruhi seseorang mendonorkan darahnya. Sebanyak 1034 subjek yang terbagi dalam dua kelompok, yakni kelompok donor 602 dan non-donor 432. Hasil penelitian tersebut memperlihatkan bahwa 405 (68,2\%) karena ingin menolong yang merupakan faktor utama mendonorkan darahnya, dan 138 $(33,1 \%)$ alasan tidak mendonorkan darhnya adalah persepsi yang buruk terhadap kesehatannya (Yang et al., 2017).

Beberapa faktor yang mempengaruhi perilaku donor darah, sebagaimana dikemukanan dalam penelitian yang dilakukan di Palang Merah Indonesia Gunung Kidul, adapun faktor yang mempengaruhi antara lain; Sikap memiliki pengaruh positif dan signifikan dalam niat mendonorkan darah secara regular. Control perilaku juga berperan signifikan dalam mendonorkan darah secara regular, semakin tinggi control perilaku seseorang maka semakin tinggi niat untuk mendonorkan darah secara regular, (Romana \& Supadmi, 2018). Jika seseorang berada dalam kondisi kritis akibat kehilanagn cairan akibat perdarahan maka transfusi merupakan tindakan yang dapat menyelamatkan nyawa seseorang. Berdasarkan pada kajian-kajian tersebut, peneliti ingin mengetahui tentang persepsi masyarakat di Desa Cihanjunag tentang donor darah. 


\section{METODE PENELITIAN}

Penlitian ini menggunakan metode kualitatif, dimana subjek sebagai sumber informasi utama. Informasi didapatkan melalui wawancara secara mendalam kepada informan yang bersedia untuk berpartisipasi dalam penelitian ini. Adapun populsi adalah masyarkat dewasa di Desa Cihanjuang. Teknik pengambilan sampel menggunakan metode nonprobability sampling dengan menggunakan teknik accidental sampling, sebanyak 7 orang dewasa yang ditemui oleh peneliti, bersedia ikut dalam penelitian ini dengan menandatangani informed consent.

Setelah menantangani inrmed consent subjek akan diberikan pertanyaan terbuka, dan setiap jawaban akan di record dengan menggunakan alat perekam. Selanjutnya investigator melakukan traskripsi dari hasil wawancara yang didapatkan. Hasil trasnkripsi selanjutnya dianalisa untuk mendapatkan kata kunci dari informan.

\section{HASIL DAN PEMBAHASAN}

Tabel 1 menunjukan gambaran demografik informan, ada 7 informan dalam penelitian ini dengan rentang usia 22-66 tahun, dimana 3 orang berjenis kelamin laki-laki dan 4 orang perempuan. Ada 5 informan yang belum pernah mendonorkan darahnya da nada 2 yang sudah pernah mendonorkan darahnya. Data tersebut juga memberikan gambaran mereka yang pernah mendonorkan darahnya adalah mereka yang berusia di bawah 23 tahun sementara mereka yang usianya lebih tua mayoritas belum pernah mendonorkan darahnya.

Gambaran penelitian ini sesuai dengan penelitian yang dilakukan terhadap 82 mahasiswa fakultas ilmu kedokteran di Tanjungpura Pontianak. Dimana 58,54\% memiliki pengetahuan yang baik, $85,4 \%$ memiliki sikap yang baik terhadap donor darah namun sebanyak $87,8 \%$ tidak pernah melakukan donor darah, (Sari, 2013). Hal senada juga tergambar dari penelitian yang dilakukan oleh (Majdabadi et al., 2018) dimana hanya $9.74 \%$ dari populasi usia 1833 tahun yang pernah mendonorkan darahnya, sedangkan $89,58 \%$ tidak pernah mendonorkan darahnya.

Tabel 1

Gambaran tentang data informan

\begin{tabular}{lllll}
\hline No & Inisial & Umur & Jenis Kelamin & Pernah/belum pernah donor darah \\
\hline 1 & L & 41 Tahun & Wanita & Belum pernah \\
2 & S & 66 Tahun & Pria & Belum pernah \\
3 & D & 21 tahun & Pria & Belum Pernah \\
4 & K & 23 Tahun & Wanita & Sudah pernah \\
5 & F & 22 tahun & Pria & Sudah pernah \\
6 & L & 28 Tahun & Wanita & Belum Pernah \\
7 & N & 25 Tahun & Wanita & Belum pernah \\
\hline
\end{tabular}

Sumber: Data primer 


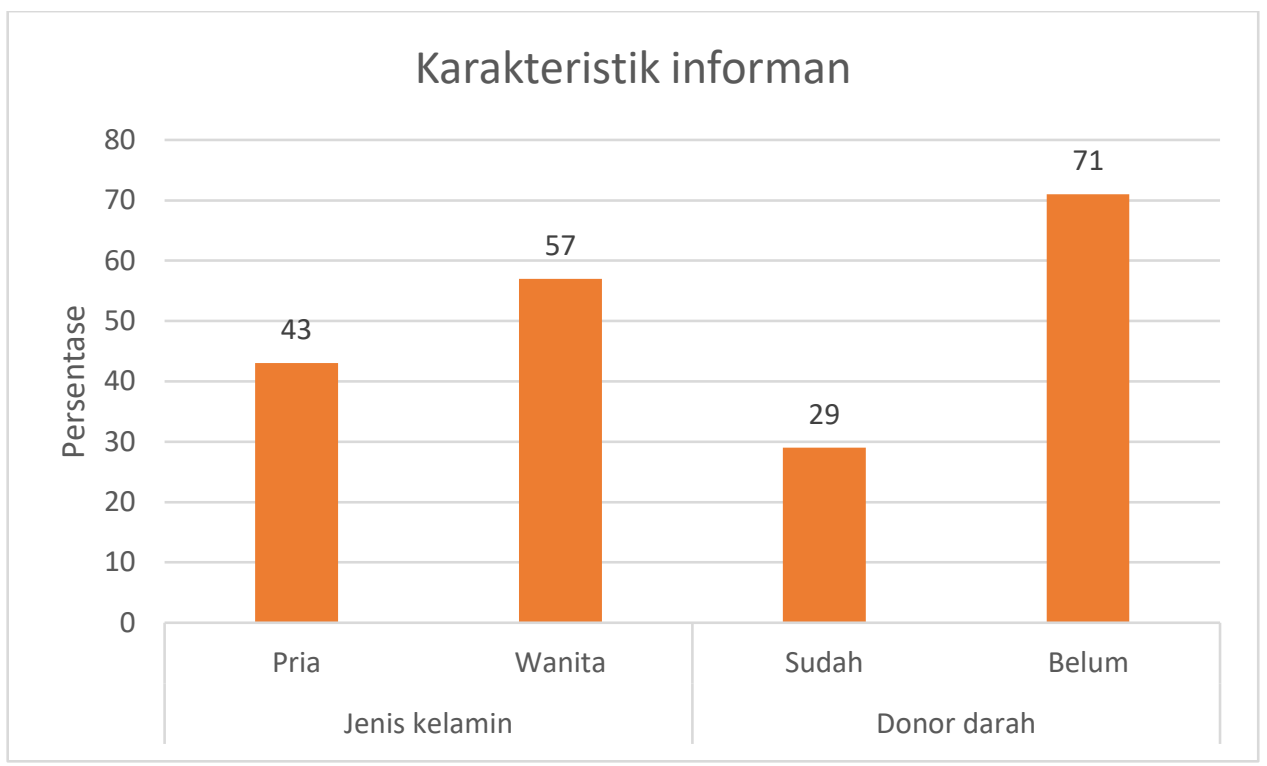

Gambar 1. Karakteristik Informan

Gambar 1 memperlihatkan karakteristik informan. Berdasarkan jenis kelamin, wanita 57\%, dan Pria 43\%. Sebayak 71\% informan belum pernah mendonorkan darahnya dan $29 \%$ sudah pernah mendonorkan darahnya. Hasil ini menunjukkan jenis kelamin wanita lebih banyak dan mayoritas belum pernah mendonorkan darahnya. Gambaran ini sesuai dengan apa yang terjadi di Nigeria, dimana penelitian tersebut menyimpulkan pengetahuan dari mahasiswa terkait donor darah tinggi, tetapi kontribusi dalam mendonorkan darahnya rendah, (Nwabueze et al., 2014).

Tabel 2

Hal yang informan ketahui tentang donor darah

\begin{tabular}{|c|c|}
\hline Emik & Kategorik \\
\hline I 1: "Naon ya, neng. Nyumbangin weh darah ke orang nu butuh.” & Kognator: \\
\hline $\begin{array}{l}\text { I 2: "Oh, donor darah itu untuk menyumbangkan darahnya untuk oramg yang } \\
\text { memerlukan." }\end{array}$ & $\begin{array}{l}\text { - Menyumbangkan } \\
\text { darah }\end{array}$ \\
\hline I 3: "Saya tidak tahu, saya belum pernah donor darah." & - Membentuk darah \\
\hline $\begin{array}{l}\text { I 4: "Donor darah teh, diambil darahnya supaya pembentukan darah baru, } \\
\text { ya." }\end{array}$ & $\begin{array}{l}\text { baru } \\
\text { - } \quad \text { Menolong orang lain }\end{array}$ \\
\hline $\begin{array}{l}\text { I 5: "Donor darah yang saya ketahui, darah kita diambil untuk menolong } \\
\text { orang, untuk kesehatan juga, gitu aja sih yang saya tahu." }\end{array}$ & \\
\hline I 6: "Donor darah, darahnya diambil dimasukin ke kantong terus tampung. & \\
\hline Misalnya ada yang butuh donor darahnya dikasih ke orang itu." & \\
\hline $\begin{array}{l}\text { I 7: "Yang saya tahu sih donor darah itu kita ngasih darah ke orang lain kalau } \\
\text { misalnya dia butuh." }\end{array}$ & \\
\hline
\end{tabular}

Sumber : Data Primer

Tabel 2 menunjukkan apa yang informan ketahui tentang donor darah. Ada 3 kognator yang informan ketahui tentang donor darah, yang pertama menyumbangkan darah, kedua membentuk darah baru dan ketiga menolong orang lain. Sebuah penelitian yang dilakukan di Nigeria terhadap 294 subjek, sebanyak
$59,5 \%$ pernah mendonorkan darahnya faktor motivasi yang mendorong mereka untuk mendonorkan darahnya yaitu untuk menyelamatkan teman atau keluarga, (Nwabueze et al., 2014). Kognator yang muncul dalam penelitian ini, sejalan dengan hasil penelitian yang dilakukan di Sukabumi, terkait dengan apa yang mereka 
pahami tentang donor darah. Sebagian besar mempersepsikan bahwa donor darah merupakan tindakan untuk merelakan sejumlah darah untuk diberikan kepada orang lain (Makiyah, 2018).

Tabel 3

Kesiapan untuk mendonorkan darah kepada orang yang tidak dikenal

\begin{tabular}{lc}
\hline Emik & Kategorik \\
\hline I 1 : "Ya siap ajalah, neng." & Kognator: \\
I 2: "Kalau misalnya untuk orang yang tidak dikenal sih saya belum gitu & $\bullet \quad$ Bersedia \\
I 3: "Kalau ini mah bisa, kalau saya bisa."Ya, insya Allah neng." & Jika ada yang butuh \\
I 4: "Kalau misalnya orangnya butuh, saya siap neng." & \\
I 5: "Bersedia saja." & \\
I 6: "Aduh, gimana yah. Kayak takut sih sebenarnya. Kita tidak kenal, jadi & \\
& \\
I 7: "Bebih mending ke orang yang dikenal saja." & \\
\hline
\end{tabular}

Sumber: Data Primer

Tabel 3. Memberikan gambaran kesediaan dalam mendonorkan darah kepada orang lain, mayoritsa informan bersedia untuk mendonorkan darah kepada orang yang tidak dikenal serta jika ada yang membutuhkan. Hasil penelitian tentang hal yang memotivasi keinginan untuk mendonorkan darah selain ingin adalah ingin menolong orang yang membutuhkan baik yang dikenal seperti keluarga atau teman maupun orang asing yang sama sekali tidak dikenal (Huis in 't Veld et al.,
2019). Sikap altruism yang melandasi keinginan menolong orang lain dengan tulus merupakan motivasi yang membuat seorang donor mau mendonorkan darah (Suen et al., 2020). Penelitian lain menunjukkan bahwa pendonor menyatakan sikap bersedia mendonorkan darah kepada anggota keluara dan kenalan namun demikian sebagian besar juga bersedia mendonorkan darah sekalipun tidak mengenal resepien (Alsalmi et al., 2019).

Tabel 4

Apakah ada Perasan terpaksa untuk mendonorkan darah.

\begin{tabular}{|c|c|}
\hline Emik & Kategorik \\
\hline $\begin{array}{l}\text { I 1: "Ya saya ah, sok sok aa neng. Kalalu tensi normal, terus kalau nolong orang } \\
\text { mah saya sok aja. Asalkan jangan merugikan saya, saya mampu } \\
\text { melakukannya ya udah weh... Gitu neng." } \\
\text { I 2: "Tidak tidak, tidak pernah." "Oh iya, ikhlas neng." } \\
\text { I 3: "Gak, gak lah. Kalau misalnya untuk membantu mah siap." } \\
\text { I 4: "Sejauh ini enggak ya, neng." "Karena kan seperti yang sudah dibilang, ya. } \\
\quad \text { Selain untuk kesehatan teh, donor darah bisa bantu orang lain yang butuh, } \\
\text { neng." } \\
\text { I 5: "Tidak sama sekali." "Pertama, ingin mencoba aja rasanya donor darah. } \\
\text { Setelah itu, tidak ada dampak apa-apa. Kalau ada donor darah lagi, saya } \\
\text { akan mendonorkan darah saja." } \\
\text { I 6: "Nggak sih. Kalau terpaksa, kenapa harus ikut?" } \\
\text { I 7: "Oh, tidak. "Pengen nolong orang lain, ya saya sukarela." }\end{array}$ & $\begin{array}{l}\text { Kognator: } \\
\text { - } \quad \text { Iklas } \\
\text { - } \quad \text { Sukarela } \\
\text { - } \quad \text { Bantu orang lain }\end{array}$ \\
\hline
\end{tabular}

Sumber : Data Primer

Tabel 4 memperlihatkan gambaran perasaan dari informan ketika mendonorkan darah mereka, yakni bersifat iklas, sukarela dan membantu orang lain atau yang membutuhkan. Menurut gubernur jawa timur, Khofifah Indar Parawansa, sifat keikhlasan, kerelawanan bagi pendonor tanpa pandang suku rasa dan agama atau tidak diskriminasi dalam 
memberikan darahnya merupakan nilai kemanuasiaan yang penting dan patut diteladani, (Arianto, 2019). Donor darah merupakan tindakan mulia bagi sesame manusia yang membutuhkan, oleh kerena dengan mendonorkan darah, kita belajar keiklasan untuk memberikan sesuatu yang berharga kepada siapa saja tanpa memandang siapa yang akan menerima darahnya, (Inmas, 2017)

Tabel 5

Perasaan jika bisa mendonorkan darah

\begin{tabular}{|c|c|}
\hline Emik & Kategorik \\
\hline I 1: “Iya, mungkin nolong orang jadi ada rasa kepuasan sendiri neng gitu.” & Kognator: \\
\hline I 2: "Merasa senang, iyaa merasa senang gitu." & - Puas \\
\hline I 3: "Biasa saja setelah mendonorkan darah ya sudah saya sudah bantu orang lain" & - $\quad$ Senang \\
\hline I 4: “"Istirahat yang cukup. Kan suka lemes-lemes." & - $\quad$ Bisa bantu \\
\hline I 5: "Istirahat, melakukan aktivitas seperti biasa." & orang \\
\hline I 6: "Istirahat." & \\
\hline $\begin{array}{l}\text { I 7: "Kalau misalnya saya sudah pernah donor darah sekali, saya akan donor darah } \\
\text { lagi dan saya senang bisa bantu orang itu bisa hidup." }\end{array}$ & \\
\hline
\end{tabular}

Tabel 5 memberikan gambaran dari informan, bahwa mayoritas merasa puas dan senang bisa membantu orang lain jika mereka bisa mendonorkan darahnya. Pendapat pendonor bahwa mendonorkan darah dimotivasi dengan keinginan menjadi penolong bagi yang membutuhkan (Mohammed \& Essel, 2018). Mendonorkan darah memberikan efek positif kepada pendonor diantaranya perasaan sehat fisik dan mental, merasa puas senang dan bangga (Hinrichs et al., 2008).

Penelitian yang dilakukan pada pendonor yang telah sering mendonor dan yang baru pertama kali mendonor menunjukkan bahwa para responden memiliki emosi psikologi diantaranya senang, bahagia, bangga dan puas setelah mendonorkan darah. Walaupun sebelum melakukan donor ada rasa takut dan stress (Williams et al., 2018). Bahkan para pendonor darah platelet yang menjalani proses donor yang lebih lama dan kompleks menyatakan lebih senang karena bisa menyelamatkan orang lain dengan mendonor(Yu et al., 2019).

Tabel 6

Bagi wanita yang datang bulan apakah boleh mendonorkan darahnya

\begin{tabular}{|c|c|}
\hline Emik & Kategorik \\
\hline $\begin{array}{l}\text { I 1: "Tergantung neng, misalnya darahnya atau jumlah darahnya yang dikeluarin } \\
\text { I banyak. Jadi, ya begitulah neng.", } \\
\text { I 2: "Itu gak boleh itu, gak bisa saja.," } \\
\text { I 3: "Datang bulan? Hmm.. Datang bulan mah bisa." } \\
\text { I 4: "Kurang tau, neng." } \\
\text { I 5: "Kalau itu saya tidak tahu. Saya bukan wanita soalnya, boleh-boleh saja } \\
\text { kayaknya." } \\
\text { I 6: "Nggak sih menurut saya.," } \\
\text { I 7: "Saya rasa sih tidak, karena kan kita lagi ngeluarin darah. Kalau kita ngeluarin } \\
\\
\text { lagi, jadi makin lemah." }\end{array}$ & $\begin{array}{l}\text { Kognator: } \\
\text { - Tidak bisa }\end{array}$ \\
\hline
\end{tabular}

Sumber : Data Primer

Tabel 6 memberikan gambaran pandangan informan tentang apakah seorang wanita yang mengalami menstruasi dapat mendonorkan darahnya, dimana informan 
mengatakan bahwa wanita yang mestruasi tidak dapat mendonorkan darahnya. Menurut (Fadli, 2019), Seseorang yang sedang menstruasi tidak dianjurkan untuk mendonorkan darahnya, hal ini dikarenakan pengurangan zat besi yang akan membuat sesorang menjadi lemas, pusing dan pinsang.

Tabel 7

Apakah donor darah merugikan atau meyehatkan

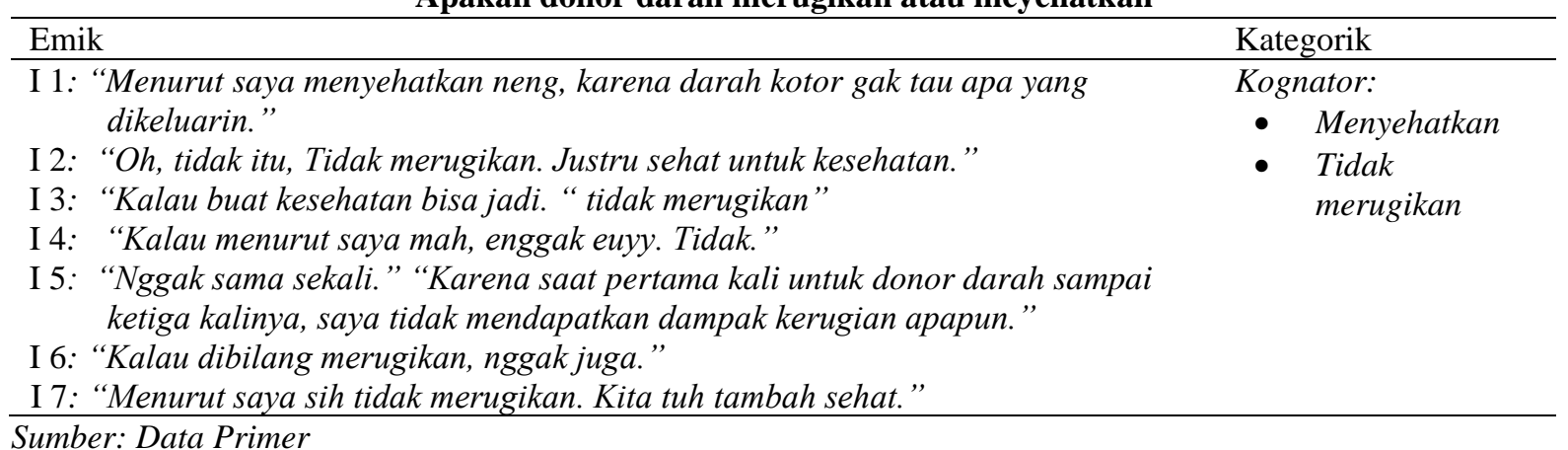
Sumber: Data Primer

Tabel 7 Memberikan pandangan informan, tentang apakah mendonorkan darah itu merugikan atau menyehatkan, mayoritas menyatakan mendonorkan darah menyehatkan dan tidak merugikan. Donor darah dapat memperlancar aliran darah, sehingga mencegah terjadinya penyumbatan arteri. Selain itu sel-sel darah baru akan dibentuk, hal ini terjadi karena saat donor darah sel darah merah berkurang, sehingga sumsum tulang belakang akan segerah menghasilkan selsel darah merah yang baru, (Fadli, 2020).

\section{KESIMPULAN}

Berdasarkan hasil wawancara terhadap 7 informan serta analisa kognator yang dilakukan, maka didaptkan kesimpulan berikut ini: Pemahaman informan tentang donor darah antara lain; menyumbangkan darah, membentuk darah baru dan menolong orang lain. Untuk kesiapan mendonorkan darahnya kepada orang yang tidak dikenal kognatornya adalah bersedia dan jika ada yang membutuhkan. Untuk perasaan dalam
Hal senada dikemukakan oleh.. manfaat dari donor darah atara lain; Menurunkan resiko penyakit jantung. Hal ini akibat viskositas darah akan menurun. Donor darah juga dapat mengeluarkan zat besi yang berlebihan, walaupun digunakan untuk membentuk sel darah merah, namun jumlah yang berlebihan akan menumpuk di pembuluh darah. Di samping itu dengan mendonorkan darah kita dapat mengetahui kondisi kesehatan kita secara gratis, dimana tensi akan di ukur, berat badan dikukur, $\mathrm{HB}$, serta pemeriksaan penyakit yang menular, (Anggraini, 2019)

mendonorkan darahnya, informan mengatakan iklas, Sukarela dan bantu orang lain. Perasaan informan ketika mendonorkan darah antara lain puas, senang dan bisa bantu orang lain. Pemahaman mereka tentang apakah orang yang menstruasi dapat mendonorkan darahnya secara bulat menyatakan tidak bisa. Informan juga menyatakan bahwa mendonorkan darah itu menyehatkan dan tidak merugikan. 


\section{DAFTAR PUSTAKA}

Alsalmi, M. ., Almalki, H. ., Alghamdi, A. ., \& Aljasir, B. . (2019). Knowledge, attitude and practice of blood donation among health professions students in Saudi Arabia; A cross-sectional study Mo. Journal of Family Medicine and Primary Care, 8(7), 2322-2327. https://doi.org/DOI:

10.4103/jfmpc.jfmpc_415_19

American Red Cross. (2016). 2016 Annual Report Bringing Communities Hope. American Red Cross And, 24. https://www.redcross.org/images/ME DIA_CustomProductCatalog/m64340 273_Annual-Report-2016.pdf

Anggraini, D. N. (2019, September). Sejuta Manfaat Sehat Rutin Donor Darah. Klik Dokter.

https://www.klikdokter.com/infosehat/read/3632775/sejuta-manfaatsehat-rutin-donor-darah

Arianto, Y. (2019). Khofifah Sebut Orang Paling Ikhlas Adalah Pendonor Darah. Bangsa Online. https://bangsaonline.com/berita/6683 3/khofifah-sebut-orang-paling-ikhlasadalah-pendonor-darah

Bethesda. (2017). Blood Transfusion. National Heart, Lung, and Blood Institute.

https://www.nhlbi.nih.gov/healthtopics/blood-transfusion

Ernes, Y. (2020, September 19). Imbas Pandemi COVID-19, PMI Kekurangan Stok Darah Sejak 2 Bulan Lalu. Detik News. https://news.detik.com/berita/d5179711/imbas-pandemi-covid-19pmi-kekurangan-stok-darah-sejak-2bulan-lalu

Fadli, R. (2019, September). Donor Darah saat Menstruasi, Bolehkah? Halodoc. https://www.halodoc.com/artikel/don or-darah-saat-menstruasi
Fadli, R. (2020). Jangan Salah, Ini Manfaat dan Efek Samping Donor Darah. Halodoc.

https://www.halodoc.com/artikel/inila h-manfaat-dan-efek-samping-donordarah

Firmansyah, R. (2020, September 20). Stok Darah Menipis, PMI Kota Bandung Ajak Warga Donor Darah. PRFMNEWS.

https://prfmnews.pikiran-

rakyat.com/bandung-raya/pr13757594/stok-darah-menipis-pmikota-bandung-ajak-warga-donordarah

Hinrichs, A., Picker, S., Schneider, A., Lefering, R., Neugebauer, E. A. ., \& Gathof, B. (2008). Effect of blood donation on well-being of blood donors. Transfusion Medicines, 18, 40-18.

https://doi.org/https://doi.org/10.1111 /j.1365-3148.2007.00805.x

Huis in 't Veld, E. M. ., de Kort, W. L. ., \& Merz, E. . (2019). Determinants of blood donation willingness in the European Union: a cross-country perspective on perceived transfusion safety, concerns, and incentives. Transfusion, 59(4). https://doi.org/https://doi.org/10.1111 /trf.15209

Inmas, S. (2017). Donor Darah Membentuk Pribadi Ikhlas. Kementrian Agama. https://jateng.kemenag.go.id/warta/be rita/detail/donor-darah-membentukpribadi-ikhlas

Majdabadi, H. A., Kahouei, M., Taslimi, S., \& Langari, M. (2018). Awareness of and attitude towards blood donation in students at the Semnan University of Medical Sciences. Electron Physician, 10(5). https://doi.org/https://dx.doi.org/10.1 9082\%2F6821

Makiyah, A. (2018). ANALISIS 


\section{PERSEPSI MASYARAKAT TERHADAP PENTINGNYA PENGETAHUAN DONOR DARAH BAGI KESEHATAN. Perpus ID UMMI. http://eprints.ummi.ac.id/257/1/ANA LISIS PERSEPSI MASYARAKAT TERHADAP PENTINGNYA.pdf}

Mohammed, S., \& Essel, H. B. (2018). Motivational factors for blood donation, potential barriers, and knowledge about blood donation in first-time and repeat blood donors. BMC Hematology, 18(1), 1-9. https://doi.org/10.1186/s12878-0180130-3

Nwabueze, S. ., Nnebue, C. ., Azuike, C. ., Ezenyeaku, Aniagboso, C. ., Ezemonye, O. ., \& Azuike, E. . (2014). Perception of Blood Donation among Medical and Pharmaceutical Science Students of Nnamdi Azikiwe University, Awka. Open Jurnal of Preventive Medicine, 4(7). https://doi.org/http://www.scirp.org/jo urnal/PaperInformation.aspx?PaperID $=47740$

Pusdatin Kemenkes. (2018). Situasi Pelayanan Darah di Indonesia (p. 7). file:///F:/Pelayanan-darah-diindonesia-2018-final.pdf

Romana, F., \& Supadmi, S. (2018). FAKTOR-FAKTOR YANG MEMPENGARUHI NIAT UNTUK BERDONORDARAH SECARA REGULER DI UNIT TRANFUSI DARAH PALANG MERAH INDONESIA KABUPATEN GUNUNGKIDUL. Jurnal Ilmu Kesehatan Bhakti Setya Medika, 3, 110. https://www.jurnal.poltekkesbsi.ac.id/index.php/bsm/article/view/4
$0 / 13$

Sari, S. E. (2013). GAMBARAN PENGETAHUAN, SIKAP, DAN TINDAKAN DONOR DARAH PADA MAHASISWA FAKULTAS KEDOKTERAN UNIVERSITAS TANJUNGPURA PONTIANAK [Tanjungpura University]. https://jurnal.untan.ac.id/index.php/jf k/article/viewFile/1775/1721

Suen, L. K. P., Siu, J. Y. M., Lee, Y. M., \& Chan, E. A. (2020). Knowledge level and motivation of Hong Kong young adults towards blood donation: a cross-sectional survey. BMJ Open, $10(1)$.

https://doi.org/10.1136/bmjopen2019-031865

Williams, L. A., Masser, B., van Dongen, A., Thijsen, A., \& Davison, T. (2018). The emotional psychology of blood donors: a time-course approach. ISBT Science Series, 13(1), 93-100. https://doi.org/10.1111/voxs.12385

Yang, J. O., Bei, C. H., \& Rong, He, X. (2017). Factors influencing blood donation: a cross-sectional survey in Guangzhou, China. Transfusion Medicines, 27(4). https://doi.org/https://doi.org/10.1111 /tme.12410

Yu, C., Lau, J. T. F., Zhong, W., Huang, X., Pan, C., Chen, Y., Lu, H., Zhao, F., Zeng, S., Lai, J., Tie, C., Li, X., Zhang, J., Zhang, C., Liu, Y., \& Jiang, Q. (2019). Why some donors are more willing to donate platelets?-A qualitative study on 25 regular platelet donors in Guangzhou, China. BMC Public Health, 19(1), 1-8. https://doi.org/10.1186/s12889-0197783-0 